\title{
Evaluation of Internship Practices in Vocational Colleges According to the Views of Academics (Kirklareli University Case) ${ }^{*}$
}

\author{
Fatma Oya Aktas ${ }^{1}$, Isil Tuzun Arpacioglu ${ }^{2}$, Ertug $\mathrm{Can}^{3}$ \\ ${ }^{1}$ Ins. Dr., Kirklareli University, Babaeski Vocational College, Department of Foreign Trade, Turkey \\ ${ }^{2}$ Ins., Kirklareli University, Babaeski Vocational College, Department of Finance, Banking and Insurance, Turkey \\ ${ }^{3}$ Asst. Prof. Dr., Kirklareli University, Faculty of Science and Literature, Department of Educational Science, Turkey \\ Correspondence: Ertug CAN, Kirklareli University, Faculty of Science and Literature, Department of Educational \\ Science, Turkey.
}

Received: October 27, 2018

Accepted: October 27, 2018

Online Published: November 29, 2018

doi:10.11114/jets.v6i11a.3801

URL: https://doi.org/10.11114/jets.v6i11a.3801

\begin{abstract}
Within the scope of university-industry cooperation, efforts on the preservation of the updating the educational programs in vocational colleges, re-arrangement of the education programs by determining the requirements of the enterprises and transferring the new technologies of the enterprises to the vocational colleges continue Within this scope, different internship application methods are applied in different universities. The compulsory internship of the student is controlled by the academic staff who are assigned as an internship advisor. Therefore, the first hand feedbacks are gathered by the advisors. For this reason, advisors' views on the practice of compulsory internship practice are an important data that must be referred to accomplish the mission of vocational colleges. In this research, it is aimed to collect the remarks of advisors in vocational colleges affiliated to Kirklareli University with regard to compulsory internship practice and different internship practice methods. The research was carried out in the spring semester of 2017-2018 academic year with the participation of teaching staff of Vocational Colleges of Kirklareli University. A total of 89 teaching staff participated in the research on the basis of volunteerism. Participants' opinions on internship practices were collected through 6 open-ended questions. The research was carried out using the purposive sampling method in qualitative research design and the obtained data were evaluated with the help of content analysis. According to findings, current internship practice was found to be inefficient in terms of the duration of internship, problems caused by workplace, low number of establishments in the region and responsibilities of students. The recommendation of the advisors, to implement a more effective internship, is to improve university-industry cooperation, increase supervision and communication.
\end{abstract}

Keywords: internship, $3+1$ method, vocational college, university-industry cooperation

\section{Introduction}

The total workload of education in vocational colleges has been determined as 120 ECTS (European Credit Transfer System). However compulsory internships are only 8 ECTS in the vocational colleges affiliated to Kirklareli University.

Compulsory internship is an important field in which the educated student gains professional awareness, has the opportunity to apply her/his theoretical knowledge and observes the applications for the profession. This practice is one of the most common ways school-industry cooperation is put into practice. According to Özel \& Karagöz (2014, 34), compulsory internship applications are to bring together the needs of the industry with the outputs of vocational colleges. Therefore, compulsory internship is one of the most important components of education, especially in vocational colleges. The follow up of compulsory internship practice of the students is carried out by the departmental instructor who is appointed as the internship adviser and the priority feedbacks are followed by the instructors in compulsory internship applications. Therefore, it is important to determine the opinions of the internship advisors. The studies on the subject are generally concerned with the opinions of the students. There is a need for sufficient level of

${ }^{*}$ This study was supported by Kirklareli University Scientific Research Projects Coordination Unit with the project number KLÜBAP-166. 
study for the instructors regarding internship applications. For this reason, this research aims to fill this gap in the literature. As an internal stakeholder, the views of the teaching staff can be an important source of data for the work that will be undertaken at universities that are planning a transition to a new internship model. At the macro level, the analysis of the views of the instructors may contribute to the improvement in vocational college education and therefore to the development in the labor force.

According to data gathered from $\operatorname{OECD}(2017 \mathrm{a}, 12)$, Turkey, although developed in the last 15 years in terms of its contribution to the labor force in the global value chain, does not raise qualified staff to meet the needs of the workforce in technologically advanced sectors. The lack of trained staff to meet this need is an obstacle to the development of such high-tech sectors in the country. According to another OECD report (2017b), unemployment rate among young people in OECD countries in 2017 was 12\%, in Turkey the figure is over 20\% (25.6\% for women and $17.8 \%$ for men). For Turkey to take an advantageous position in global competition, labor skills have to be determined by the needs of the sectors and students must be equipped with these needed skills. This will be realized only by improving in university-industry communication. Therefore mandatory internship practice is important since it is the most common and traditional form of this communication.

The traditional "summer internship" which is being applied in higher education is generally criticized because it takes 15-40 working days and it cannot be applied while education is going on (Sarıbıyık, 2013, 39-41), it is inefficient due to its short duration and it is difficult to supervise (Üncü, 2013, 68-72). However the new formulas have advantages and disadvantages as well. In $3+1$ model, the student spends one semester at the work place and 3 semesters at the vocational college. It is aimed to facilitate the supervision of the students in the scope of university-workplace co-ordination among the workplaces in the district or city where the vocational school is located. In this model, the possibility of a longer internship is an advantage. However, there are problems that have not yet been met in practice.

Determining the semester during which the student's internship will take place is important both in terms of student satisfaction and productivity and the spring semester provides an advantage to the student (Arpat et al., 2017, 76). The low number of businesses in the place where the vocational school is located is the biggest disadvantages (Sarıbiylk, 2013 , 41). Contrary to the summer internship, internship options framed in a particular location is a disadvantage for the vocational college, especially in the non-industrialized areas.

Data about career orientation of the students provides important preliminary information for universities regarding the future life of students (Warshaw \& Davis, 1985). Career choice according to the personal characteristics and competencies of the students will make gains for both the student and the labor market (Tinsley, 2000). Therefore, efforts to determine the student's personal characteristics and qualifications are very important. As Mohammed \& Rashid (2016) and Verquer et al. (2003) pointed out, it would be possible during the internship application to find out whether the characteristics of the student are overlapping the needs of the market, since the students can be tested directly on the job, while clarifying their career orientation as well. In this respect, internship practice and continuous updating of this practice are of great importance.

The aim of this research is to make a general evaluation of internship practices in vocational colleges according to the opinions of the instructors and to develop suggestions for the improvement of internship practices.

The problem statement of the research was expressed as "How are the internship practices in the vocational colleges affiliated to the University of Kirklareli?" and in this context, tanswers for the following questions were sought:

1. Is the practicing internship efficient/sufficient for the student/internship place?

2. What is the level of the instructors' knowledge about alternative internship practices?

3. What activities are carried out at vocational colleges for appraisal/renewal studies for internship applications?

4. What are the opinions and recommendations of the instructors for a more effective internship application?

\section{Method}

The research was conducted for the academic staff working at six vocational colleges affiliated to Kirklareli University (Babaeski, Lüleburgaz, Vize, Sosyal Bilimler, Sağlık Hizmetleri, Pınarhisar Vocational Colleges).

A total of 89 teaching staff participated in the research on the basis of volunteerism. The research was carried out in the spring semester of 2017-2018 academic year with the participation of teaching staff of Vocational Colleges of Kirklareli University. Qualitative method was used in the research. The research consists of two parts. In the first part, it is aimed to collect demographic information of the participants. In the second part, participants' opinions on internship practices were collected through 6 open-ended questions. Demographic data and quantitative research data were evaluated by percentage and frequency. Participants in the second part of the study were asked; How do they find the internship application which is still being implemented in Kirklareli University in terms of student/internship place; Whether or not they have 
sufficient information about alternative internship practices other than the continuing internship program at Kirklareli University; their Views on the new practice of internship planned at Kirklareli University; what preparatory works were carried out in your vocational college/department, regarding the internship application planned to be carried out at Kirklareli University; the suggestions for a more effective internship application. Finally, they are asked to state their general opinions on the subject.

The research was carried out using the purposive sampling method in qualitative research design and the obtained data were evaluated with the help of content analysis. As stated by Teddlie and Tashakkori $(2015,209)$, in the qualitative part of the study "criterion sampling technique of purposeful sampling methods" was used to "obtain a lot of details from a small number of situations for a certain purpose, to provide depth and rich data". In this way, it is aimed to study in depth the situations that are thought to have rich knowledge by means of purposeful sampling. In order to ensure the health of the data, it was taken as a basic criterion to apply the views of all teaching staff in vocational schools.

In the research, in the process of content analysis, similar data were gathered together on the basis of certain common concepts and themes, and the data were interpreted in such a way that the reader could understand (Yıldırım and Şimşek, 2006). The data of the study were analyzed under a total of 10 themes (Table 7, Table 8 and Table 9).

In order to obtain the data of the study, a questionnaire consists of 10 open-ended questions was developed by the researchers based on literature review and field research. This questionnaire was applied to 10 instructors as a focus group and examined by 3 instructors specialized in educational sciences. In accordance with the results of the pilot scheme and the opinions of the field experts, necessary corrections have been made in the questionnaire. Then, it was decided to eliminate 4 open-ended questions in the questionnaire and in the end, the questionnaire consists of 6 structured open-ended questions and the form became ready for the application stage. The participants were asked to respond in written form to the 6 open-ended questions in the questionnaire. The data of the study were obtained in written form from 89 instructors.

The validity of the qualitative research has been defined as that the researcher observes the phenomena s/he investigates as objectively and as impartially as possible (Kirk \& Milller, 1986, cited by Yıldırım \& Şimşek, 2006). In this respect, the form was validated. In order to ensure the reliability of the research, the findings are presented by coding the participant's opinions directly and by specifying the participant numbers (P1, P2, P3 etc.).

In order to ensure the validity of the study, the findings were interpreted in the presentation of the data, taking into consideration the situation related to the data. The themes were determined according to the theoretical structure. After data analysis to provide internal reliability, all findings were presented without comment (Creswell, 2015, 250-254). The opinions expressed by each participant were reviewed two or three times, and the accuracy of those mentioned was confirmed by three researchers. The extracted codes were then re-analyzed and associated with the themes (Bogdan \& Biklen, 1998).

In addition, expert opinion was sought to verify whether the opinions represented the themes. The lists of the participants' views and themes were evaluated by 3 faculty members who are experts in educational sciences. First, the field experts were asked to match the participant's opinions with the themes in the list, then the mappings of the field experts were compared to the mappings of the researchers. In order to determine the reliability of the coding, the formula 'Reliability = Consensus Union / (Consensus + Opinion) X100' was applied (Miles and Huberman, 1994, 64). The fit between the encoders was calculated as .88. In order to ensure the external validity of the study, the research section, study group, data collection tool and data analysis processes are explained in detail.

\subsection{Limitations of Research}

The data of this study is limited to the opinions of the teaching staff in Kirklareli University. The research is limited to written answers to 6 open-ended questions. In addition, research is limited to internship practices in vocational schools.

\section{Findings}

Participants' demographic data were analyzed in the first part of the study.

Table 1. Gender of Participants

\begin{tabular}{|c|c|c|}
\hline Gender & Freq. & $\%$ (Appr.) \\
\hline Male & 46 & 51.6 \\
\hline Female & 43 & 48.3 \\
\hline Total & 89 & 100,0 \\
\hline
\end{tabular}

As can be seen in Table 1, 46 of the 89 participants were male and 43 were female and a balanced distribution has emerged. 
Table 2. Distribution according to the participants' vocational colleges

\begin{tabular}{lcc}
\hline Vocational Colleges & Freq. & \% (Appr.) \\
\hline Babaeski VC & 6 & 7 \\
Health Services VC & 10 & 11 \\
Social Sciences VC & 16 & 18 \\
Luleburgaz VC & 13 & 15 \\
Pinarhisar VC & 21 & 23 \\
Vize VC & 21 & 23 \\
Total & $\mathbf{8 9}$ & $\mathbf{1 0 0 , 0}$ \\
\hline
\end{tabular}

As shown in Table 2, the research was conducted for the teaching staff working at six vocational colleges affiliated to Kirklareli University. 16 participants are from Babaeski MYO, 10 from Health Services Vocational College, 16 from Social Sciences Vocational College, 13 from Lüleburgaz Vocational College, 21 from Pinarhisar Vocational College and 21 from Vize Vocational College.

Table 3. Academic Title of Participants

\begin{tabular}{lcc}
\hline Academic Title & Freq. & \% (Appr.) \\
\hline Ins. & 85 & 4.5 \\
Asst. Prof. & 4 & 95.5 \\
Total & $\mathbf{8 9}$ & $\mathbf{1 0 0 , 0}$ \\
\hline
\end{tabular}

The distribution of participants by title is shown in Table 3. According to this, 4 of the academic staff participating in the research are assistant professors and 85 of them are instructors.

Table 4. Distribution of administrative duties

\begin{tabular}{|c|c|c|}
\hline Administrative Duty & Freq. & \%(Appr.) \\
\hline Department Head & 11 & 12.3 \\
\hline Center Director & 1 & 1 \\
\hline Deputy Head & 6 & 6.7 \\
\hline None & 71 & 79.7 \\
\hline Total & 89 & 100,0 \\
\hline
\end{tabular}

As shown in Table 4, 18 lecturers have administrative duties in the form of department head, center director and deputy head.

Table 5. Distribution according to experience of internship advisor

\begin{tabular}{lccc}
\hline An Internship Advisor & & Freq. & \%(Appr.) \\
\hline Have been & 69 & 77.5 \\
Have not yet been & 20 & 22.5 \\
Total & $\mathbf{8 9}$ & $\mathbf{1 0 0 , 0}$ \\
\hline
\end{tabular}

As shown in Table 5, the majority of the participants (69) had previously served as an internship advisor.

Table 6. Awareness about internship application models.

\begin{tabular}{llcccc}
\hline Internship Models & Aware of. & \% (Appr.) & Unaware of. & \% (Appr.) \\
\hline $3+1$ & 70 & 78.6 & 19 & 21.3 & \\
Trimester & 74 & 83 & 15 & & 16.8
\end{tabular}

As it can be seen in Table 6,19 of the participants do not have knowledge about $3+1$ internship practice model and 15 do not have knowledge of trimester internship model.

A total of 40 days of two-stage compulsory internship practice is available at the vocational colleges of the University of Kirklareli with STAJ13001 and STAJ13002 codes and with 0 credits and 4 ECTS, to be carried out during the summer term. While 26 of the academics participating in the research found this application to be sufficient, a large majority (63) find it totally or partially inefficient. Table 7 presents the reasons for the academics who find the internship application is inefficient/inadequate. 
Table 7. Reasons for finding the ongoing internship practice ineffective/insufficient

\begin{tabular}{|c|c|}
\hline Theme & Explanation \\
\hline Length & $\begin{array}{l}\text { - "I think that the internship period is very short and that sufficient experience and } \\
\text { knowledge can not be created during this period." (P6) } \\
\text { - "I think that a 40-day internship is inadequate for students to be able to promote } \\
\text { themselves and their talents." (P42) }\end{array}$ \\
\hline $\begin{array}{l}\text { Workplace problems } \\
\text { (indifference, } \\
\text { unwillingness to employ } \\
\text { interns, } \\
\text { non-vocational work for } \\
\text { students). }\end{array}$ & $\begin{array}{l}\text { - "The fact that the hospital personnel are not willing to take the interns and the } \\
\text { student does not have the opportunity to do internship on the field where the student } \\
\text { is trained makes the practice insufficient. Depending on the increase in quotas, the } \\
\text { number of students which increase every year also reduces the efficiency." (P16) } \\
\text { - "I think that work places are not reluctant and available for teaching interns the } \\
\text { job." (P30) }\end{array}$ \\
\hline $\begin{array}{l}\text { Inadequacy of companies } \\
\text { in the region. }\end{array}$ & $\begin{array}{l}\text { - "The number of students to do an internship is much higher than the internship } \\
\text { quota of businesses." (P20) } \\
\text { - "We do not have internship opportunities for our departments. Almost all of our } \\
\text { students have to find internships in other cities." (P28) } \\
\text { - "Vize is a small district and students are having trouble finding an internship } \\
\text { place." (P74) }\end{array}$ \\
\hline $\begin{array}{l}\text { Not fulfilling the } \\
\text { responsibilities assigned } \\
\text { to the students }\end{array}$ & $\begin{array}{l}\text { - "Neither the employers nor the students take this internship very seriously." } \\
\text { (K55) } \\
\text { - "Most of the interns do not go to the work place. This, in turn, removes the gains } \\
\text { from the internship." (P56) } \\
\text { - "Since the students find the internship places themselves, they are doing } \\
\text { internships in places that are outside the province, as "fake" internship. In } \\
\text { addition, employers do not want trainees at the work place." (P63) } \\
\text { - "The workplace must conform to the theoretical training of the student. Because } \\
\text { the student can ditch the day easily. S/he can do a fake internship. Or s/he may have } \\
\text { to do an internship in a workplace that does not benefit her/him because of the } \\
\text { hardship." (P89) }\end{array}$ \\
\hline
\end{tabular}

As seen in Table 7, participants who participated in the research and found the existing internship application as inefficient, stated that the internship period of $20+20=40$ days are inadequate. This is in parallel with the previous research and literature. According to participants, a short internship period leads to an ineffective internship experience. Secondly, the participants have expressed concerns about workplaces where internships are to be conducted and have emphasized that workplaces do not want to employ interns or that interns are forced to accomplish tasks that are not related to their education. The third issue highlighted by the participants is the limited number of enterprises in the region. It is stated that living in the small city and the small districts is disadvantageous for students to find an internship place. The fourth emphasized issue is that students are not fulfilling their responsibilities for compulsory internship. According to the participants, the students do not take internship seriously and apply "fake internship", which is called "internship without going to work place". According to participants, the second and fourth problem is the lack of supervision of internship practice. Because of this lack of supervision, both the workplace and the student create an inefficiency about the main purpose of the internship application.

It is planned that the application of $3+1$ internship at the vocational colleges of Kirklareli University will start from 2018-2019 academic year and studies are being carried out by vocational colleges. Almost half of the participants (43) stated that they have no knowledge about alternative internship practices except the internship application already applied at Kirklareli University. The other half of the participants (46) stated that they were informed and they indicated " $3+1 "$ and "trimester" applications as alternative systems. Three themes for the knowledge level of the participants on different internship practices are highlighted and presented in Table 8.

These are; 3+1 application is expressed as Trimester, 3+1 and Trimester systems are defined without confusion, examination of applications in other universities. 
Table 8. Level of knowledge about different internship practice models

\begin{tabular}{ll}
\hline Theme & Explanation \\
\hline Misnaming 3+1 & -"Trimester internship practice is a new concept that is becoming widespread in many \\
as Trimester & $\begin{array}{l}\text { universities in our country. In this application, the student has } 3 \text { semesters of inclass } \\
\text { education and } 1 \text { semester of internship at the workplace." (P2) }\end{array}$ \\
& - "I have information about the trimester. An application involving students to take internships \\
& during the 4th semester after taking 3 semesters of the theoretical course." (P14) \\
& - "I have information about Trimester. The system based on the student taking 3 semester of \\
& courses and 1 semester in practice." (P16)
\end{tabular}

Examining the - "3+1.3 semester courses 1 semester internship, I had the opportunity to examine the system applications in of Sakarya University." (P1)

the other - "Trimester: TOBB ETU has been practicing for 10 years. Those who pass through two or universities. more semesters, in one semester during the year are going to internship. At that time classes are not opened (sometimes they can create disadvantage). When graduated, the student graduates with 1-1.5 years of experience." (P43)

- "I have information about 3+1 internship practices at Sakarya University. 3 semesters of courses and 1 semester of internship period can be evaluated as good and bad according to the physical conditions of the relevant university and the provincial/district coordination." (P70)

- "For example, the $3+1$ internship is being implemented in universities integrated with the industry. Sakarya University sends students who have successfully completed the 3-semester theory course for the "vocational college" and have achieved sufficient success and conditions to the industry, during the 4th semester. Students are insured and paid for their internship. Of course, the advantage of being in Sakarya University's industrial zone for this system can not be denied. However Kirklareli University is not too far away from industrialization. Applicability is based on the close relationship and cooperation between our university and the industry." (P89)

As seen in Table 8, it is often seen that the "trimester" expression is used to name the $3+1$ system and the information is not clear and the two systems are mixed. Other participants, who indicated that they have knowledge about alternative internship practices, can describe $3+1$ and trimester applications without confusion.

Participants who indicated that they were aware of the alternate internship practice indicated that they were examining applications in other universities.

30 of the 89 new participants were positive for the new internship program which will be implemented in Kirklareli University, 26 were evaluated as neither positive nor negative and 24 were found that as negative. A large majority of the participants (72) stated that for the $3+1$ system planned for Kirklareli University, one department of their collegel was chosen as the pilot application department, the other departments had curriculum and adaptation work, and they also worked on the new internship direction. 10 of the participants stated that they had studied similar internship practices in other universities and vocational colleges, and 8 of them had carried out studies on provinces or districts where vocational colleges were located which would become an important stakeholder together with the new application.

Participants expressed their proposals for a more effective internship application under three headings: internship place, internship period and internship procedure, which are presented in Table 9. 
Table 9. Suggestions for implementing a more effective internship

\begin{tabular}{ll}
\hline Theme & Explanation \\
\hline Enterprises & There should be cooperation between university-work place and other institutions \\
& (Turkish Employment Organization etc.). \\
& The internship must be supervised and the communication should be increased with \\
the work place. & Student must be provided internship opportunities in other cities. \\
\hline Internship term & Internship should only be in spring \\
& Internship must be spread over two semesters \\
\hline Procedure & Completely re-planned
\end{tabular}

As can be seen in Table 9, participants suggested to make internships more effective, to increase university-workplace co-operation, to enable the supervision of the student at the internship place, to have the internship in the spring semester or to equally spread the studenst among two semesters and to reorganize the internship procedure.

Finally, the participants were asked whether they had any opinions they wanted to add about the topic. In response to this question, the participants repeated their views and did not add a different view than the answers given to the first five questions.

\section{Results, Conclusion and Recommendations}

According to the findings of the study, all participants agree that the internship is an important component of education in vocational colleges. A large part of the participants agree that the current summer internship is inefficient. The summer internship is criticized because of its short period and the problems in the supervision. Therefore, in response to the first question, whether the practicing internship application is productive/sufficient in terms of student/internship place? the answer appears as "inefficient / insufficient". As the answer to the second question of the research, "Do the instructors have enough knowledge about alternative internships?", half of the respondents (43) stated that they had no knowledge about the subject, while the other half (46) stated that they had knowledge about the subject, but they showed that they did not have sufficient knowledge by mixing the names of different applications. Therefore, the vast majority of participants do not have sufficient knowledge about alternative internship practices.

The third question of the research, which studies/works are being carried out at vocational colleges for evaluation/renewal the internship applications? participants indicated that the new curriculum work was carried out in the vocational college they were affiliated with, the researches were carried out on the work places where the internships would be held, and the applications in other universities were examined. Most of the participants are cautious about new practice options, thinking that new internship systems in the direction of the results of the research will prevent the inefficiency of the internship practices already in place.

In response to the question "what are the opinions and recommendations of the instructors for implementing a more effective internship?" the participants emphasized firstly the necessity for increasing the duration of internship in the current system. In studies in other universities, the short period of the summer internship was pointed, it was stated that training period should be increased, the student should intern at least one semester (Bektaş \& Tuğay, 2016) or even one year (Küçükgöksel \& Akpınar, 2016). Participants also criticized the application of $3+1$ internship which is planned for Kirklareli University and focused on the semester and establishments where internships will be implemented. Part of the participants believed that the implementation of the $3+1$ system is more advantageous in the spring period. Participants who stated that the spring semester was advantageous indicated that after the internship in the spring semester the students were more likely to be hired as full time employees in the place where they had internships. Arpat et al. (2017, 83) conducted a survey of vocational colleges that applied $3+1$ system and found that student satisfaction was higher in spring semester than in the fall semester.

Most of the participants stated that students who are trained in small cities and districts with $3+1$ system will have difficulty in finding an internship place. In order to overcome these difficulties, it is proposed by the participants a cooperation between the university and the workplace and giving the students the opportunity to practice in other cities. On a local basis, this problem can be overcome by industry cooperation protocols with the university.

For example, in the scope of university-stakeholder cooperation, the people of the districts, local governments and industrial organizations have collaborated with the vocational college and designed training programs by developing new 
vocational programs according to the needs of the business world and the times we are in (Öktem \& Şahin, 2011). According to the results of a similar survey, the level of satisfaction of the students who practice internship under a similar university-industry collaboration protocol, the students increased their vocational qualifications as a result of the internship period, they had experience and knowledge about the related business area and also expansed the field of knowledge (Dündar et al., 2014). In addition, by this way, it will be ensured that workplaces can closely follow the vocational colleges and their activities and the role of the industry in the growth of the labor force will be increased. Because business world has not positive attitude towards vocational college graduates and their opinions about interns from vocational colleges can not be considered positive as well. For example, according to the findings of the research conducted by İçli (2007) in the Lüleburgaz county, it is clear that the view of the enterprises towards the vocational college graduates is in the negative direction. As stated by Küçükgöksel \& Akpınar $(2016,16)$ as a result of university-industry cooperation, it is crucial for the employers not to see students as cheap labor force, necessary to take legal precautions for educating the students as a future, trained personnel, and to take necessary security precautions at work places.

One of the most important criticisms about summer internship is the problem of supervision. Participants often touched upon the problems created by the lack of supervision of the student who was interning at the workplace. This opinion is also parallel to the opinions of the students who are doing internship. In Marmara University, Tektaş et al. (2016) associate degree students were asked to evaluate the internship application and consequently the results were obtained that the students in the workplace did not receive adequate training and that they did not have the opportunity to improve their skills by their workplaces. Students stated that this problem arises from the fact that the workplace where they are practicing is not adequately supervised by the coordinators in the universities they are affiliated with (Tektaş et al., 2016, 313). In one study, students pointed out the fact there was no supervisory mechanism as one of the biggest problems related to the internship (Dolmac1 \& Duran, 2017). Regarding the overcoming of the supervision problem, supervision can be presented as a solution through online programs, by increasing the university-workplace coordination and by means of an online system linked to this coordination, as a solution (Üncï, 2013, 68-72). Furthermore, according to Titrek, Hakkakul \& Varlı $(2015,275)$ education at school is not sufficient for internship practices.

As a result, the instructors think that one of the most important components of vocational education in higher education is applied education in the workplace and that the practical training or mandatory internship in the workplace should be developed and transformed. Within this transformation or renewal, it has been revealed that the extension of the internship period, the increase of university-industry cooperation and the increase of supervision in workplace education is needed in particular. In order to be able to make these improvements, alternative internship practices for the traditional summer internship, especially the $3+1$ system, seem to be the strongest alternative. The scope of the research, it is revealed that most of the participants do not have enough knowledge about the $3+1$ system planned to be applied in the vocational colleges they are working at. However, most of the participants think that the semester based workplace application should be done in the spring term. The biggest concern of the participants is that if the $3+1$ system is applied, there will be a negative situation in the province of Kurklareli due to the low number of establishments to be interned in. For this reason, the establishment of university-industry protocols or the possibility of doing internships outside the city can help to overcome the problems arise in finding an internship place. According to the findings of the research, finding an internship place and supervising the training of the students is also expressed as a problem. Problems arise when students are supervised even in a relatively short summer period. Problems arising in the workplace education of the students can not be controlled. In a workplace practice that will last for a semester, the student will be trained in the workplace for a period of about twice the length of the traditional summer internship. Therefore, effective supervision of internship practices is of great importance. According to findings in the research, it may be useful to sign workplace protocols, to inform instructors and staff well, to update departmental programs, to use research data, and to perform infrastructure developments for the implementation of workplace environment in the university in order to overcome basic problems.

\section{References}

Arpat, B., Kalfa, V. R., Akşit, A., \& Çamurdan, B. (2017). Meslek yüksekokullarında nitelikli ara eleman ihtiyacını karşılamada yeni arayışlar: 3+1 işbaş1 eğitim modeli Honaz Meslek Yüksekokulu örneği. Journal of Labour Relations, 8(2), 76-94.

Bektaş, M., \& Tuğay, O. (2016). Sosyal bilimler alanında staj çalışmasının yeri ve önemini belirlemeye yönelik bir araştırma. Uluslararası Alanya İşletme Fakültesi Dergisi, 8(2), 165-174.

Bogdan, R. C., \& Biklen, S. K. (1998). Qualitative research for education: An introduction to theory and methods (3rd ed.). Boston, MA: Allyn and Bacon.

Creswell, J. W. (2015). Qualitative research methods (Trans. Ed. M. Bütün \& S. B. Demir). Ankara: Siyasal.

Dolmacı, N., \& Duran, Y. (2017). Ön lisans düzeyinden öğrenim gören öğrencilerin zorunlu staj uygulamasına ilişkin 
görüşleri, sorunları ve çözüm önerileri: Isparta Meslek Yüksekokulu örneği. Mehmet Akif Ersoy Üniversitesi Sosyal Bilimler Enstitüsü Dergisi, 9(21), 254-267.

Dündar, B., Yılmaz, H., \& Kara, Y. (2014). Mesleki ve teknik eğitimde üniversite-sanayi işbirliği protokolü yerel uygulama örneği: Yeniçağa. 21. Yüzyılda Eğitim ve Toplum, 3(8), 121-127.

İçli, G. (2007). İşletmelerin meslek yüksekokulu mezunları ile ilgili görüşleri ve beklentileri (Lüleburgaz ilçe sınırlarında faaliyet gösteren işletmeler üzerine bir araştırma). Marmara Üniversitesi İ.I.B.F. Dergisi, 13(2), 263-272.

Küçükgöksel, N. Ç., \& Akpınar, T. (2016). İstihdam odaklı meslekî eğitime yönelik sorunlar, talep ve beklentiler. Tekirdağ SMMM Odası, 6, 1-18.

Miles, M. B., \& Huberman, M. A. (1994). An expanded sourcebook qualitative data analysis. London, UK: Sage.

Mohammed, A. A., \& Rashid, B. (2016). The moderating influence of internship program on the relationship between undergraduates' perception and their intention to join tourism and hospitality industry: A theoretical model. International Review of Management and Marketing, 6(2), 317, 321.

OECD. (2017a). OECD skills Outlook 2017: Skills and global value chains. Retrieved June 7, 2018, from https://read.oecd-ilibrary.org/education/oecd-skills-outlook-2017/executive-summary_9789264273351-2-en\#page2

OECD. (2017b). Youth unemployment rate. Retrieved June 7, 2018, from https://data.oecd.org/unemp/youth-unemployment-rate.htm

Öktem, Ş., \& Şahin, F. İ. (2011). Sektör ve meslek yüksekokulu beklentilerine bir örnek: Başkent Üniversitesi Kazan Meslek Yüksekokulu'nda açılması hedeflenen programlara ilişkin bir çalışma. 2. Uluslararası, 6. Ulusal Meslek Yüksekokullarl Sempozyumu, 25-27 Mayls 2011, Aydın.

Özel, N., \& Karagöz, İ. (2014). Meslek yüksekokulları ve iş-dünyası arasında becerili insan kaynağı yetiştirme ilişkilerinin yeterliği: Bolu Meslek Yüksekokulu stajyer öğrenciler üzerinde bir araştırma, Electronic Journal of Vocational Colleges, 4(1), s. 32-41.Türk Lise Öğrencilerinde Okul Terkinin Yordanması: Aracı ve Etkileşim Değişkenleri ile Bir Model Testi

Sarıbıyık, M. (2013). Meslek yüksekokullarında nitelikli işgücü yetiştirmek için 3+1 eğitim modeli. Journal of Engineering and Science, 1(1), 39-41.

Teddlie, C., \& Tashakkori, A. (2015). Karma yöntem araştırmalarının temelleri. (Çev. Yüksel Dede ve Selçuk Beşir Demir). Ankara: Anı Yayıncılık.

Tektaş, N., Yayla, A., Sarıkaş, A., Polat, Z., Tektaş, M., \& Öz Ceviz, N. (2016). Ön lisans öğrencilerinin staj uygulamalarının değerlendirilmesi: Marmara Üniversitesi örneği. Ĕgitim ve Öğretim Araştırmaları Dergisi, 5(36), 310-318.

Tinsley, H. E. A. (2000). The congruence myth: An analysis of the efficacy of the person - Environmental fit model. Journal of Vocational Behavior, 56, 147-179. https://doi.org/10.1006/jvbe.1999.1727.

Titrek, O., Hakkakul, M. A., \& Varlı, S. (2015). Hemşirelik bölümü staj uygulamalarının etkililik düzeyine ilişkin öğrenci ve rehber hemşirlerin görüşleri. Abant İzzet Baysal Üniversitesi Eğitim Fakültesi Dergisi, 15(1), 264-280.

Üncü, İ. S. (2013). Mühendislik eğitiminde endüstri stajının internet üzerinden takibi ve değerlendirilmesi. Suleyman Demirel University Journal of Natural and Applied Science, 17(1), 68-72.

Verquer, M. L., Beehr, T. A., \& Wagner, S. H. (2003). A meta-analysis of relations between person-organization fit and work attituted. Journal of Vocational Behavior, 63, 473-489. https://doi.org/10.1016/S0001-8791(02)00036-2

Warshaw, P., \& Davis, F. (1985). Disentangling behavioral intention and behavioral expectation. Journal of Experimental Social Psychology, 21, 213-218. https://doi.org/10.1016/0022-1031(85)90017-4

Yıldırım, A., \& Şimşek, H. (2006). Sosyal Bilimlerde Nitel Araştırma Yöntemleri. Ankara: Seçkin Yayıncılık.

\section{Copyrights}

Copyright for this article is retained by the author(s), with first publication rights granted to the journal.

This is an open-access article distributed under the terms and conditions of the Creative Commons Attribution license which permits unrestricted use, distribution, and reproduction in any medium, provided the original work is properly cited. 